\title{
Analisis Tingkat Kesehatan KSPS BMT Rama Tahun 2010 Berdasarkan Metode CAMEL (Capital, Assets, Management, Efficiency, Liquidity)
}

\section{Zulfa Saiban}

Sekolah Tinggi Agama Islam Negeri Salatiga

Zsaiban@yahoo.com

\begin{abstract}
Abstrak
Health financial institution is institution that can keep their credibility in society perspective, government, and also their costumer. Health financial institution mean that those was hold operational and management based on regulation/law and manage profesional. Health level appraisal of institution is appraisal on institution/cooperation ability to holding operational activities based on regulation. Health level appraisal can used as a measurement for management to appraise their operational activities. Further more, health level appraisal can used to evaluate management and to determinite the direction of developing institution. Externally, health level appraisal can affect to loyality of the customer to their cooperation. Ordinary, health level appraisal do to financial institioun such as bank/BPR which based on the CAMEL, this analysys include capital, asset, management, efficiency, and likuidity. Especially to non-bank financial institution like cooperation add two component : growth and cooperation identity.
\end{abstract}

Keyword: health level institution, health level appraisal, BMT Rama Salatiga

\section{Pendahuluan}

BMT tumbuh dan berkembang di Indonesia serta berperan dalam mengembangkan usaha kecil melalui fasilitas pembiayaan yang relatif murah dan mudah dijangkau oleh mayoritas usaha kecil. Layaknya sebuah lembaga mikro yang tetap kebal diterpa krisis perekonomian, BMT juga mampu 
menahan terpaan krisis ekonomi. Salah satu studi yang meneliti dampak krisis ekonomi terhadap kinerja keuangan BMT justru menunjukkan bahwa ada peningkatan kinerja keuangan meskipun perekonomian makro sedang dilanda krisis (Suharyani, 1999). Krisis tersebut membuka peluang bagi BMT untuk meningkatkan mobilisasi dana mengingat adanya perbedaan karakteristik produk bank konvensional dengan lembaga keuangan syariah. BMT sebagaimana lembaga-lembaga ekonomi yang menerapkan prinsip syariat Islam, lahir bersamaan dengan semakin bergairahnya kaum muslimin untuk kembali ke ajaran Islam. Peran umum BMT adalah melakukan pembinaan dan pendanaan yang berdasarkan sistem syari'ah. Peran ini menegaskan arti penting prinsip syari'ah dalam kehidupan ekonomi masyarakat. Sebagai lembaga keuangan syari'ah yang bersentuhan langsung dengan kehidupan masyarakat kecil yang memiliki keterbatasan materi ataupun ilmu pengetahuan, maka BMT mempunyai tugas penting dalam mengemban misi keislaman dalam segala aspek kehidupan masyarakat (Heri Sudarsono, 2003). Saat ini lebih dari 3.000 BMT tersebar di seluruh nusantara, dengan asset (konsolidasi) lebih dari satu triliun rupiah, dengan jumlah pengelola lebih dari 20.000 orang, hampir setengahnya S-1 dan wanita. BMT melayani lebih dari dua juta penabung, dan memberikan pinjaman pada lebih dari 1,5 juta pengusaha mikro dan kecil (PINBUK, 2006:1).

Meskipun BMT telah mengalami perkembangan yang signifikan, keberadaan BMT di Indonesia kurang didukung oleh faktor-faktor pendukung yang memungkinkan BMT untuk terus berkembang dan berjalan dengan baik sehingga banyak BMT yang tenggelam dan bubar yang disebabkan oleh pengeloaan manajemennya yang tidak amanah dan profesional, hal ini berimplikasi pada kredibilitas BMT dalam pandangan masyarakat. Akibatnya, timbul citra yang kurang baik di masyarakat. BMT identik dengan lembaga yang buruk, tidak dapat dipercaya, hanya menjual isu syari'ah, bisnisnya orang yang ingin memiliki bank tetapi tidak mau mengikuti atutan perbankan, dan sebagainya (A.Sumiyanto, 2008:XVII).

\section{Penilaian Kesehatan BMT}

Sebagai lembaga keuangan yang beroperasi layaknya sebuah perbankan, maka BMT dituntut untuk beroperasi secara amanah dan 
profesional. Salah satu cara untuk mengukur kinerja sebuah BMT dapat dilakukan melalui Penilaian tingkat kesehatan BMT. Baitul maal wattamwil merupakan Koperasi Jasa Keuangan, maka Penilaian Kesehatannya merujuk pada Peraturan Menteri Nomor: 20/Per/M.KUKM/XI/2008 Tentang Pedoman Penilaian Kesehatan Koperasi Simpan Pinjam dan Unit Simpan Pinjam Koperasi berikut perubahannya Nomor : 14/Per/M.KUKM/XII/2009. Penilaian Koperasi Jasa Keuangan yang mencakup aspek-aspek dan komponen analisis sebagai berikut :

\section{Permodalan ( Capital)}

Aspek permodalan bertujuan untuk mengetahui bagaimana tingkat kemampuan modal koperasi dengan pendekatan kuantitatif antara lain dilakukan melalui penilaian terhadap komponen-komponen sebagai berikut:

a. Rasio Modal sendiri terhadap total aset

Rasio ini merupakan perhitungan dari modal sendiri (jumlah nilai akun di dalam equity dengan catatan SHU tidak termasuk dan untuk akun penyertaan dinilai hanya dinilai 50\% ) dibagi dengan jumlah total Asset dalam neraca dikalikan $100 \%$ pada saat penilaian.

Rasio ini memiliki sasaran penilaian yaitu sejauh mana kemampuan koperasi menghimpun dana dan seberapa besar tingkat keseimbangan keamanan modal sendiri (equity).

b. Rasio Kecukupan Modal sendiri $(C A R)$

Rasio ini adalah modal sendiri tertimbang (Jumlah modal sendiri yang dikalikan dengan bobot pengakuan risiko) dibagi dengan Aktiva Tertimbang Menurut Risiko (Jumlah komponen aset dalam neraca dikalikan dengan bobot pengakuan risiko ) dikalikan 100\% pada saat penilaian.

Rasio ini bertujuan untuk mengukur kecukupan modal minimal dalam rangka pengamanan resiko aktiva produktif. Sehingga dalam hal ini nilainya berbentuk linier semakin tinggi semakin baik.

\section{Kualitas Aktiva Produktif (Asset quality)}

Aspek kualitas aktiva produktif untuk mengetahui bagaimana tingkat keamanan dana pinjaman terhadap alokasi piutang baik pada anggota atau 
non anggota dengan didasarkan pada komponen analisis sebagai berikut:.

a. Rasio Risiko Pinjaman Bermasalah terhadap Pinjaman Diberikan

Rasio ini merupakan perbandingan antara Risiko Pinjaman Bermasalah (jumlah dari : 50\% PKL; 75\% PDR dan 100\% PM) dibagi dengan Pinjaman Diberikan (sisa dari pinjaman pokok yang belum dikembalikan) kali $100 \%$ pada saat penilaian.

Rasio ini bertujuan untuk mengukur prosentase tingkat Pinjaman Bermasalah (Non Performance Loan/NPL) sehingga semakin kacil rasio adalah semakin aman kondisi koperasi dan sebaliknya semakin besar maka semakin terancam keberadaan koperasi tersebut.

b. Rasio Pinjaman yang Berisiko terhadap Pinjaman yang Diberikan Rasio ini menganalisis prosentase Pinjaman Berisiko dibagi pinjaman yang diberikan kali $100 \%$ pada saat penilaian. Analisis rasio ini bertujuan untuk mengukur kualitas aset produktif terhadap potensi risiko dari pinjaman yang tidak mempunyai agunan yang memadai atau jaminan penjamin/avalis yang diandalkan. Sehingga semakin rendah rasionya semakin tinggi kualitas assetnya.

\section{Manajemen (Management)}

Penilaian terhadap faktor manajemen dilakukan dengan pendekatan kualitatif terhadap penilaian komponen-komponen sejumlah 30 pertanyaaan dengan bobot skor 15 jika semua jawaban pertanyaan "Ya" untuk lebih jelasnya dapat dirinci sebagai berikut:

a. Manajemen Umum

Dinilai atas dasar 5 pertanyaan dengan bobot nilai 3 atau setiap pertanyaan mendapat skor 0,6 apabila jawaban pertanyaan " Ya " dan skor 0 jika jawaban " Tidak"

b. Manajemen Kelembagaan

Dinilai dengan 5 pertanyaan dengan bobot nilai 3 atau setiap pertanyaan mendapat skor 0,6 apabila jawaban "Ya " dan skor 0 Jika jawaban “ Tidak “

c. Manajemen Permodalan

Dinilai dengan 5 pertanyaan dengan bobot nilai 3 atau setiap pertanyaan 
mendapat skor 0,6 apabila jawaban "Ya " dan skor 0 Jika jawaban “ Tidak “

d. Manajemen Aktiva

Dinilai dengan 5 pertanyaan dengan bobot nilai 3 atau setiap pertanyaan mendapat skor 0,6 apabila jawaban "Ya " dan skor 0 Jika jawaban “ Tidak “

e. Manajemen Likuiditas

Dinilai dengan 5 pertanyaan dengan bobot nilai 3 atau setiap pertanyaan mendapat skor 0,6 apabila jawaban "Ya “ dan skor 0 Jika jawaban “ Tidak “

\section{Efisiensi (Efficiency)}

Aspek Efisiensi adalah penilaian aspek terhadap sejauhmana tingkat efisiensi kinerja koperasi sehingga pada akhirnya akan dapat memperoleh keuntungan yang optimal dengan tidak mengurangi kompetitif pelayanan kepada anggota dan non anggota. Dalam hal ini didasarkan pada analisis Rasio Beban Operasi Anggota terhadap Partisipasi Bruto. Analisis Rasio ini adalah perbandingan Beban Operasi Anggota (Jumlah beban pokok ditambah Beban Usaha Anggota dan Beban Perkoperasian / untuk USP Beban Perkoperasian dihitung secara proporsional) dibagi dengan Partisipasi Bruto (Kontribusi anggota kepada koperasi sebagai imbalan penyerahan barang dan jasa kepada anggota) kali $100 \%$. Sasaran analisis ini untuk mengetahui tingkat efisiensi beban biaya usaha dan beban organisasi jika dibanding pendapatan yang diperoleh dari anggota, sehingga semakin rendah rasio semakin efisien.

\section{Likuiditas (liquidity)}

Aspek ini digunakan untuk menganalisa dan menginterpresentasikan posisi keuangan jangka pendek dan juga sangat membantu bagi manajemen untuk efisiensi modal kerja. Dalam aspek ini dilakukan pendekatan kuantitatif dengan analisis 2 komponen sebagi berikut :

a. Pengukuran Rasio Kas + Bank terhadap Kewajiban Lancar

Rasio ini merupakan perhitungan prosentase akun Kas tunai dan dana di Bank yang dapat ditunaikan dibagi dengan Kewajiban Lancar dari neraca 
kali $100 \%$.

Pengukuran rasio ini bertujuan untuk mengukur tingkat keamanan (safety) terhadap likuiditas dana terhadap kewajiban lancar jika dibutuhkan, maka apabila rasio terlalu rendah tingkat keamanan likuiditas rendah tetapi sebaliknya jika terlalu tinggi maka tingkat efisiensi modal kerja juga sangat rendah sehingga tidak produktif.

b. Pengukuran Rasio Volume Pinjaman yang Diberikan terhadap Dana yang Diterima

Rasio ini adalah perhitungan rasio volume Pinjaman yang diberikan dibagi dengan Dana Diterima (Jumlah Total Kewajiban dan Modal didalam neraca selain Biaya yang masih harus dibayar dan Hutang Pajak dan SHU Belum Dibagi) kali 100\%.

Perhitungan rasio ini untuk mengukur kemampuan Koperasi menyalurkan dari dana yang diterima (LDR) sehingga semakin tinggi nilai rasio semakin produktif atau semakin baik kinerjanya akan tetapi ada batas maksimal penyaluran untuk menyisihkan dana cadangan hutang (requirment) minimal $5 \%$ untuk menjaga kondisi likuidasi hutang.

\section{Kemandirian dan Pertumbuhan (Growht)}

Aspek ini digunakan untuk menilai tingkat kemandirian dan pertumbuhan usaha Koperasi dengan melakukan pendekatan Rasio Rentabilitas AsetRasio Rentabilitas Asset atau biasa disebut Return on Asset (ROA) adalah rasio perbandingan Sisa Hasil Usaha (SHU) sebelum Pajak dibagi dengan total Asset (Nilai total seluruh asset yang ada dalam neraca) kali seratus persen. Rasio ini dapat digunakan untuk menilai tingkat kinerja koperasi terhadap kebijakan investasi baik dalam modal kerja maupun dalam asset tetap.

\section{Jati diri koperasi}

Aspek ini merupakan penilaian koperasi terhadap jatidiri koperasi yang merupakan karakteristik utama Koperasi yang membedakan dengan Badan Usaha lain dimana anngota koperasi memiliki identitas ganda (the dual identity of the member) yaitu anggota sebagi pemilik dan sekaligus pengguna jasa Koperasi (user own oriented firm) pendekatan penilaian melalui 
rasio partisipasi bruto. Rasio partisipasi bruto adalah pengukuran rasio partisipasi bruto (jumlah kontribusi anggota terhadap hasil usaha koperasi) dibagi dengan partisipasi bruto ditambah pendapatan (pendapatan yang diterima dari transaksi dengan non-anggota).

\section{Analisis tingkat kesehatan KSPS BMT RAMA}

1. Permodalan

a. Rasio modal sendiri terhadap total aset

modal sendiri X $100 \%$

total asset

Tabel 3.1

RasioModal sendiri Terhadap total aset

\begin{tabular}{|c|c|c|c|c|}
\hline $\begin{array}{c}\text { Rasio Modal } \\
(\%)\end{array}$ & Nilai & Bobot (\%) & Score & Kriteria \\
\hline 0 & 0 & 5 & 0 & $0-1,25$ tidak sehat \\
\hline 5 & 25 & 5 & 1,25 & $1,26-2,50$ kurang sehat \\
\hline 10 & 50 & 5 & 2,50 & $2,51-3,75$ cukup sehat \\
\hline 15 & 75 & 5 & 3,75 & $3,76-5,0$ sehat \\
\hline 20 & 100 & 5 & 5,0 & \\
\hline
\end{tabular}

Sumber : PERMEN NO :35.3/Per/M.UKM/X/2007

Perhitungan modal sendiri

\begin{tabular}{|l|r|}
\hline \multicolumn{1}{|c|}{ komponen modal } & \multicolumn{1}{c|}{ nilai } \\
\hline cadangan & $8,793,119$ \\
simpanan pokok & $15,515,000$ \\
simpanan wajib & $21,098,500$ \\
penyertaan(diakui 50 \%) & $148,500,000$ \\
& $193,906,619$ \\
\hline
\end{tabular}

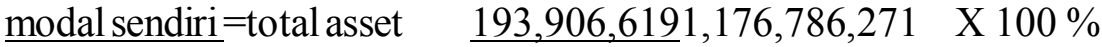

$$
=16.48 \%
$$

Rasio modal sendiri terhadap total aset sebesar $16,48 \%$. ini berarti rasio modal sendiri terhadap total aset memiliki kriteria sehat. 
b. Rasio kecukupan modal (CAR) modal tertimbang ATMR

X $100 \%$

Tabel 3.2

Rasio CAR

\begin{tabular}{|c|c|c|c|c|}
\hline $\begin{array}{c}\text { Rasio CAR } \\
(\mathbf{\%})\end{array}$ & Nilai & $\begin{array}{c}\text { Bobot } \\
(\%)\end{array}$ & Score & Kriteria \\
\hline$<6$ & 25 & 5 & 1.25 & Tidak sehat \\
\hline $6-<7$ & 50 & 5 & 2.50 & Kuranpg sehat \\
\hline $7-<8$ & 75 & 5 & 3.75 & Cukup sehat \\
\hline$\geq 8$ & 100 & 5 & 5.00 & sehat \\
\hline
\end{tabular}

Sumber : PERMEN NO :35.3/Per/M.UKM/X/2007

\section{Perhitungan Modal Tertimbang}

\begin{tabular}{|l|r|r|r|}
\hline komponen modal & \multicolumn{1}{|c|}{ nilai } & \multicolumn{1}{c|}{ bobot } & \multicolumn{1}{|c|}{ MT } \\
\hline simpanan pokok & $15,515,000$ & $100 \%$ & $15,515,000$ \\
simpanan wajib & $21,098,500$ & $100 \%$ & $21,098,500$ \\
modal penyertaan & $297,000,000$ & $50 \%$ & $148,500,000$ \\
cadangan umum & $8,793,119$ & $100 \%$ & $8,793,119$ \\
cadangan resiko & $1,011,400$ & $50 \%$ & 505,700 \\
hibah & $18,400,000$ & $100 \%$ & $18,400,000$ \\
\hline \multicolumn{3}{|r}{} \\
\hline
\end{tabular}

$$
\frac{\text { modal sendiri }}{\text { total asset }}=\frac{193,906,619}{1,176,786,271} \times 100 \%=16.48 \%
$$

Rasio modal sendiri terhadap total aset sebesar $16,48 \%$. ini berarti rasio modal sendiri terhadap total aset memiliki kriteria sehat.

\section{Kualitas Aktiva Produktif}

a. Rasio resiko pinjaman bermasalah (RPM)

$$
\frac{\text { Jml pinjaman bermasalah }}{\text { pinjaman yg diberikan }} \text { X 100\% }
$$


Tabel 3.3

Rasio resiko Pembiayaan bermasalah (RPM)

\begin{tabular}{|c|c|c|c|c|}
\hline $\begin{array}{c}\text { Rasio } \\
(\mathbf{\%})\end{array}$ & Nilai & $\begin{array}{c}\text { Bobot } \\
(\mathbf{\%})\end{array}$ & Score & Kriteria \\
\hline$>12$ & 25 & 10 & 2.50 & $0-<2.5$ tidak lancar \\
\hline $9-12$ & 50 & 10 & 5.00 & $2.5-<5$ kurang lancar \\
\hline $5-8$ & 75 & 10 & 7.50 & $5.0-<7.5$ cukup lancar \\
\hline$<5$ & 100 & 10 & 10.00 & $7.5-<10$ lancar \\
\hline
\end{tabular}

Sumber: PERMEN NO :35.3/Per/M.UKM/X/2007

pembiayaan bermasalah

\begin{tabular}{|lrrr|}
\hline kurang lancar & $44,000,000$ & $50 \%$ & $22,000,000$ \\
diragukan & $4,331,000$ & $75 \%$ & $3,248,250$ \\
macet & $17,000,000$ & $100 \%$ & $17,000,000$ \\
& & & $\mathbf{4 2 , 2 4 8 , 2 5 0}$ \\
\hline
\end{tabular}

Perhitungan pinjaman yang diberikan

\begin{tabular}{|lc|}
\hline volume pembiayaan & $654,991,315$ \\
Cad. Penghapusan Piutang & $(20,472,124)$ \\
& $634,519,191$
\end{tabular}

$\frac{\text { Jml pinjaman bermasalah }}{\text { pinjaman yg diberikan }}=\frac{42,248,250}{634,519,191} \times 100 \%=6.6583 \%$

b. Rasio portofolio pembiayaan beresiko $\frac{\text { Juml. pembiayaan beresiko }}{\text { Vol. pinjaman }} \times 100 \%$

Tabel 3.4

Rasio portofolio Pembiayaan Beresiko

\begin{tabular}{|c|c|c|c|l|}
\hline Rasio (\%) & Nilai & Bobot (\%) & Score & \multicolumn{1}{|c|}{ kriteria } \\
\hline$>30$ & 25 & 5 & 1.25 & $0-<1.25$ sangat beresiko \\
\hline $26-30$ & 50 & 5 & 2.50 & $1.25-<2.50$ kurang beresiko \\
\hline $21-<26$ & 75 & 5 & 3.75 & $2.50-<3.75$ cukup beresiko \\
\hline$<21$ & 100 & 5 & 5.00 & $3.75-5.00$ tidak beresiko \\
\hline
\end{tabular}

Sumber : PERMEN NO :35.3/Per/M.UKM/X/2007 
$\frac{\text { Juml. pembiayaan beresiko }}{\text { Vol. pinjaman }}=\frac{84,231,000}{654,991,315} \times 100 \%=12.8597 \%$

Hasil penilaian rasio portofolio pembiayaan beresiko sebesar 12.8597 \% sehingga termasuk kriteria tidak beresiko

3. Manajemen

a. Manajemen Umum

Tabel 3.5

Standar Manajemen Umum

\begin{tabular}{|c|c|c|}
\hline Positif & Nilai kredit bobot & Kriteria \\
\hline 1 & 0.50 & $0-0.75$ tidak baik \\
\hline 2 & 1.00 & $0.76-1.50$ kurang baik \\
\hline 3 & 1.50 & $1.51-2.25$ cukup baik \\
\hline 4 & 2.00 & $2.26-3.00$ baik \\
\hline 5 & 2.50 & \\
\hline 6 & 3.00 & \\
\hline
\end{tabular}

Sumber : PERMEN NO :35.3/Per/M.UKM/X/2007

\section{DAFTAR PERTANYAAN}

\begin{tabular}{|c|c|c|c|c|}
\hline & Apakah KSP punya Visi, Misi dan tujuan yang jelas? & 1 & 0.6 & 0.6 \\
\hline a. 2 & Apakah KSP punya tujuan jangka panjang? & 0 & 0.6 & 0 \\
\hline a.3 & $\begin{array}{l}\text { Apakah KSP punya rencana kerja tahunan sebagai dasar } \\
\text { acuan kerja selama } 1 \text { tahun? }\end{array}$ & 1 & 0.6 & 0.6 \\
\hline a.4 & $\begin{array}{l}\text { Apakah ada kesesuaian rencana jangka pendek dengan } \\
\text { jangka panjang? }\end{array}$ & 1 & 0.6 & 0.6 \\
\hline a.5 & $\begin{array}{l}\text { Apakah pengurus, pengawas dan pengelola KSP tidak } \\
\text { melakukan hal yang merugikan koperasi untuk pribadi? }\end{array}$ & 1 & 0.6 & 0.6 \\
\hline & TOTAL & & & 2.4 \\
\hline
\end{tabular}

Total skor untuk manajemen umum 2.4, sehingga manajemen umum berada di kriteria baik 
b. Manajemen kelembagaan

Tabel 3.6

Standar manajemen kelembagaan

\begin{tabular}{|c|c|c|}
\hline Positif & Nilai kredit bobot & Kriteria \\
\hline 1 & 0.50 & $0-0.75$ tidak baik \\
\hline 2 & 1.00 & $0.76-1.50$ kurang baik \\
\hline 3 & 1.50 & $1.51-2.25$ cukup baik \\
\hline 4 & 2.00 & $2.26-3.00$ baik \\
\hline 5 & 2.50 & \\
\hline 6 & 3.00 & \\
\hline
\end{tabular}

Sumber : PERMEN NO :35.3/Per/M.UKM/X/2007

\section{DAFTAR PERTANYAAN}

\begin{tabular}{|ll|l|l|l|}
\hline b.1 & $\begin{array}{l}\text { Apakah KSP memiliki stuktur organisasi dan job } \\
\text { description? }\end{array}$ & 1 & 0.6 & $\mathbf{0 . 6}$ \\
\hline b.2 Apakah bagan operasi mencerminkan job description? & 1 & 0.6 & $\mathbf{0 . 6}$ \\
\hline b.3 Apakah KSP memeiliki dewan pengawas? & 1 & 0.6 & $\mathbf{0 . 6}$ \\
\hline $\begin{array}{l}\text { b.4 Apakah KSP memiliki sistem pengamanan yang baik } \\
\text { terhadap dokumen penting? }\end{array}$ & 1 & 0.6 & $\mathbf{0 . 6}$ \\
\hline $\begin{array}{l}\text { b.5 Apakah KSP memiliki SOP sebagai acuan kegiatan } \\
\text { operasionalnya? }\end{array}$ & 1 & 0.6 & $\mathbf{0 . 6}$ \\
\hline \multicolumn{2}{|c|}{ TOTAL } & & & $\mathbf{3 . 0}$ \\
\hline
\end{tabular}

Total skor untuk manajemen kelembagaan 3, sehingga manajemen kelembagaan berada di kriteria baik

c. Manajemen permodalan

Tabel 3.7

Standar Manajemen Permodalan

\begin{tabular}{|c|c|c|}
\hline Positif & Nilai kredit bobot & Kriteria \\
\hline 1 & 0.50 & $0-0.75$ tidak baik \\
\hline 2 & 1.00 & $0.76-1.50$ kurang baik \\
\hline 3 & 1.50 & $1.51-2.25$ cukup baik \\
\hline 4 & 2.00 & $2.26-3.00$ baik \\
\hline 5 & 2.50 & \\
\hline 6 & 3.00 & \\
\hline
\end{tabular}

Sumber: PERMEN NO :35.3/Per/M.UKM/X/2007 


\section{DAFTAR PERTANYAAN}

\begin{tabular}{|c|c|c|c|c|}
\hline c. 1 & $\begin{array}{l}\text { Tingkat pertumbuhan modal sama dengan atau lebih } \\
\text { besar dari pertumbuhan assets }\end{array}$ & 1 & 0.6 & 0.6 \\
\hline c. 2 & $\begin{array}{l}\text { Tingkat pertumbuhan modal sendiri yang berasal dari } \\
\text { anggota setidaknya } 10 \% \text { dibanding tahun lalu }\end{array}$ & 1 & 0.6 & 0.6 \\
\hline c. 3 & $\begin{array}{l}\text { Penyisihan cadangan SHU sama atu lebih besar dari } \\
\text { seperempat SHU tahun berjalan }\end{array}$ & 0 & 0.6 & 0 \\
\hline c. 4 & $\begin{array}{l}\text { Simpanan dan simpanan berjangka meningkat } 10 \% \text { dari } \\
\text { tahun sebelumnya }\end{array}$ & 1 & 0.6 & 0.6 \\
\hline c. 5 & $\begin{array}{l}\text { Investasi harta tetap dan ekspansi berasal dari modal } \\
\text { sendiri }\end{array}$ & 1 & 0.6 & 0.6 \\
\hline & TOTAL & & & 2.4 \\
\hline
\end{tabular}

Total skor untuk manajemen permodalan 2.4, sehingga manajemen permodalan berada di kriteria baik

d. Manajemen aktiva

Tabel 3.8

Standar manajemen Aktiva

\begin{tabular}{|c|c|c|}
\hline Positif & Nilai kredit bobot & Kriteria \\
\hline 1 & 0.50 & $0-0.75$ tidak baik \\
\hline 2 & 1.00 & $0.76-1.50$ kurang baik \\
\hline 3 & 1.50 & $1.51-2.25$ cukup baik \\
\hline 4 & 2.00 & $2.26-3.00$ baik \\
\hline 5 & 2.50 & \\
\hline 6 & 3.00 & \\
\hline
\end{tabular}

Sumber : PERMEN NO :35.3/Per/M.UKM/X/2007

\section{DAFTAR PERTANYAAN}

\begin{tabular}{|c|c|c|c|c|}
\hline d.1 & $\begin{array}{l}\text { Pinjaman lancar setidaknya } 90 \% \text { dari pinjaman yang } \\
\text { diberikan }\end{array}$ & 1 & 0.6 & 0.6 \\
\hline d.2 & $\begin{array}{l}\text { Setiap pinjaman didukung dengan agunan yang nilainya } \\
\text { sama atau lebih besar dari plafon }\end{array}$ & 1 & 0.6 & 0.6 \\
\hline d.3 & Ada rapat komite dalam keputusan realisasi pembiayaan & 1 & 0.6 & 0.6 \\
\hline d.4 & $\begin{array}{l}\text { Pinjaman macet tahun lalu dapat ditagih setidaknya } \\
\text { sepertiganya }\end{array}$ & 1 & 0.6 & 0.6 \\
\hline d.5 & $\begin{array}{l}\text { Menggunakan prudential banking dalam reallisasi } \\
\text { pembiayaan }\end{array}$ & 1 & 0.6 & 0.6 \\
\hline & TOTAL & & & 3.0 \\
\hline
\end{tabular}


Total skor untuk manajemen aktiva 3.0, sehingga manajemen aktiva berada di kriteria baik

e. Manajemen likuiditas

Tabel 3.9

Standar Manajemen Likuiditas

\begin{tabular}{|c|c|c|}
\hline Positif & Nilai kredit bobot & Kriteria \\
\hline 1 & 0.50 & $0-0.75$ tidak baik \\
\hline 2 & 1.00 & $0.76-1.50$ kurang baik \\
\hline 3 & 1.50 & $1.51-2.25$ cukup baik \\
\hline 4 & 2.00 & $2.26-3.00$ baik \\
\hline 5 & 2.50 & \\
\hline 6 & 3.00 & \\
\hline
\end{tabular}

Sumber : PERMEN NO :35.3/Per/M.UKM/X/2007

\section{DAFTAR PERTANYAAN}

Total skor untuk manajemen likuiditas 2.4, sehingga manajemen likuiditas berada di kriteria baik

\section{Efisiensi}

\begin{tabular}{|c|c|c|c|}
\hline $\begin{array}{c}\text { e.1 } \\
\text { Memiliki kebijaksanaan tertulis mengenai pengendalian } \\
\text { likuiditas }\end{array}$ & 0 & 0.6 & $\mathbf{0}$ \\
\hline $\begin{array}{c}\text { e.2 } \\
\text { Memiliki fasilitas pinjaman dari lembaga lain untuk } \\
\text { menjaga likuiditas }\end{array}$ & 1 & 0.6 & $\mathbf{0 . 6}$ \\
\hline $\begin{array}{c}\text { e.3 } \\
\text { memiliki pedoman administrasi yang efektif untuk }\end{array}$ & 1 & 0.6 & $\mathbf{0 . 6}$ \\
\hline $\begin{array}{c}\text { e.4 Kebijakan funding dan lending sesuai keadaan keuangan } \\
\text { koperasi }\end{array}$ & 1 & 0.6 & $\mathbf{0 . 6}$ \\
\hline e.5 Memiliki SIM yang memadai untuk pemantauan likuiditas & 1 & 0.6 & $\mathbf{0 . 6}$ \\
\hline TOTAL & & & $\mathbf{2 . 4}$ \\
\hline
\end{tabular}

a. Rasio operasi pelayanan terhadap partisipasi bruto beban operasi anggota X 100\% partisipasi bruto 
Tabel 3.10

Rasio operasi pelayanan terhadap partisipasi bruto

\begin{tabular}{|c|c|c|c|c|}
\hline Rasio ( \%) & Nilai & Bobot (\%) & Score & Kriteria \\
\hline$>100$ & 25 & 4 & 1.00 & Tidak efisien \\
\hline $85-100$ & 50 & 4 & 2.00 & Kurang efisien \\
\hline $69-84$ & 75 & 4 & 3.00 & Cukup efisien \\
\hline $0-68$ & 100 & 4 & 4.00 & Efisien \\
\hline
\end{tabular}

Sumber : PERMEN NO :35.3/Per/M.UKM/X/2007

Beban operasi anggota

\begin{tabular}{|lr|}
\hline beban usaha & $179,210,341$ \\
beban pokok & $14,181,321$ \\
& $193,391,662$ \\
\hline
\end{tabular}

partisipasi bruto

\begin{tabular}{|lr|}
\hline pendapatan bahas MSA & $6,957,850$ \\
pendapatan bahas BBA & $165,239,500$ \\
pendapatan adm. & \\
Pembiayaan & $30,851,850$ \\
& $203,049,200$ \\
\hline
\end{tabular}

beban operasi anggota $=\underline{193,391,662} \times 100 \%$

$$
95.2437 \%
$$

partisipasi bruto 203,049,200

Hasil pengukuran rasio ini sebesar $95.2437 \%$, sehingga termasuk dalam kriteria kurang efisien

b. Rasio aktiva tetap terhadap total asset

$\underline{\text { aktiva tetap }}=\mathrm{X} 100 \%$

Total asset 
Tabel 3.11

Rasio Aktiva terhadap total asset

\begin{tabular}{|c|c|c|c|c|}
\hline Rasio ( \%) & Nilai & Bobot (\%) & Score & Kriteria \\
\hline $76-100$ & 25 & 4 & 1 & Tidak baik \\
\hline $51-75$ & 50 & 4 & 2 & Kurang baik \\
\hline $26-50$ & 75 & 4 & 3 & Cukup baik \\
\hline $0-25$ & 100 & 4 & 4 & baik \\
\hline
\end{tabular}

Sumber : PERMEN NO :35.3/Per/M.UKM/X/2007

$$
\frac{\text { aktiva tetap }}{\text { Total asset }}=\frac{301,144,087}{1,176,786,271} \times 100 \%=25.5904 \%
$$

Hasil pengukuran rasio ini adalah $25.5904 \%$ sehingga termasuk dalam kriteria baik.

\section{Likuiditas}

a. Rasio kas

kas dan bank $\quad$ X $100 \%$

kewajiban lancar

Tabel 3.12

Rasio Kas

\begin{tabular}{|c|c|c|c|c|}
\hline Rasio Kas ( \%) & Nilai & Bobot (\%) & Score & Kriteria \\
\hline$<14$ dan $>56$ & 25 & 10 & 2.5 & Tidak likuid \\
\hline$(14-20)$ dan (46-56) & 50 & 10 & 5.0 & Kurang likuid \\
\hline$(21-25)$ dan (35-45) & 75 & 10 & 7.5 & Cukup likuid \\
\hline $26-34$ & 100 & 10 & 10 & likuid \\
\hline
\end{tabular}

Sumber : PERMEN NO :35.3/Per/M.UKM/X/2007

$\begin{array}{llll}\text { kas dan bank } & = & \underline{220,647,993} & \times 100 \%\end{array}=27.455 \%$

Hasil penghitungan rasio ini sebesar $27.455 \%$ sehingga termasuk dalm kriteria likuid 
b. Rasio volume pembiayaan terhadap dana yang diterima

Volume pembiayaan $\quad$ X $100 \%$

dana yang diterima

Tabel 3.13

Rasio Pembiayaan terhadap dana yang diterima

\begin{tabular}{|c|c|c|c|c|}
\hline Rasio pembiayaan (\%) & Nilai & Bobot (\%) & Score & Kriteria \\
\hline$<50$ & 25 & 5 & 1,25 & Tidak likuid \\
\hline $51-75$ & 50 & 5 & 2,5 & Kurang likuid \\
\hline $76-100$ & 75 & 5 & 3,75 & Cukup likuid \\
\hline$>100$ & 100 & 5 & 5 & likud \\
\hline
\end{tabular}

Sumber : PERMEN NO :35.3/Per/M.UKM/X/2007

Dana Yang Diterima

total kewajiban dan modal

$$
\begin{array}{r}
1,176,786,271 \\
710,000 \\
1,176,076,271 \\
\hline
\end{array}
$$

biaya yang masih harus dibayar

Volume pembiayaan $=\underline{654,991,315} \times 100 \% \quad=55.6929 \%$ dana yang diterima $1,176,786,271$

Hasil pengukuran rasio ini sebesar $55.6929 \%$ sehingga tergolong dalam kriteria kurang likuid.

\section{Kemandirian dan Pertumbuhan}

a. ROA

EBT $\quad X \quad 100 \%$

total assets

Tabel 3.15

Rasio rentabilitas aset

\begin{tabular}{|c|c|c|c|c|}
\hline Rasio Rentabilitas Aset ( \%) & Nilai & Bobot (\%) & Score & Kriteria \\
\hline$<5$ & 25 & 3 & 0.75 & Rendah \\
\hline $5-7.4$ & 50 & 3 & 1.50 & Kurang \\
\hline $7,5-10$ & 75 & 3 & 2.25 & Cukup \\
\hline$>10$ & 100 & 3 & 3,00 & tinggi \\
\hline
\end{tabular}

Sumber : PERMEN NO :35.3/Per/M.UKM/X/2007 
$\underline{\mathrm{EBT}}=\underline{12,323,821} \times 100 \% \quad=1.04724 \%$

total assets $1,176,786,271$

Hasil penghitungan rasio ini adalah $1.04724 \%$, sehingga termasuk dalam kriteria rendah.

\section{Jati Diri Koperasi}

a. Rasio partisipasi bruto partisipasi bruto $\quad$ X 100\% partisipasi bruto + pendapatan non anggota

Tabel 3.16

Rasio Partisipasi Bruto

\begin{tabular}{|c|c|c|c|c|}
\hline Rasio (\%) & Nilai kredit & Bobot (\%) & Skor & Kriteria \\
\hline$<25$ & 25 & 5 & 1.25 & Rendah \\
\hline $25-49$ & 50 & 5 & 2.50 & Kurang \\
\hline $50-75$ & 75 & 5 & 3.75 & Cukup \\
\hline$>75$ & 100 & 5 & 5.00 & tinggi \\
\hline
\end{tabular}

Sumber : PERMEN NO :35.3/Per/M.UKM/X/2007

Partisipasi Bruto

\begin{tabular}{|lr|}
\hline pendapatan bahas MSA & $6,957,850$ \\
pendapatan bahas BBA & $165,239,500$ \\
pendapatan adm. & $30,851,850$ \\
Pembiayaan & $203,049,200$ \\
\hline
\end{tabular}

\section{Partisipasi Bruto Dan Non Anggota}

\begin{tabular}{|lr|}
\hline $\begin{array}{l}\text { partisipasi bruto } \\
\text { pendapatan }\end{array}$ & $203,049,200$ \\
& $203,049,200$ \\
\hline
\end{tabular}

$\underline{\text { partisipasi bruto }}=\underline{203,049,200} \times 100 \% \quad=100 \%$ partisipasi bruto + pendapatan non anggota $203,049,200$ 
Hasil penghitungan rasio ini sebesar $100 \%$ sehingga termasuk dalam kriteria tinggi.

\section{Penut up}

Berdasarkan hasil analisis CAMEL terhadap beberapa komponen dapat disimpulkan bahwa tingkat kesehatan KSPS BMT RAMA berada dalam kriteria sehat, dengan berdasarkan penilaian aspek:

1. Permodalan

a. Rasio modal sendiri terhadap total aset sebesar $16,48 \%$. ini berarti rasio modal sendiri terhadap total aset memiliki kriteria sehat.

b. Hasil penghitungan CAR sebesar $24.16 \%$. berarti rasio CAR memiliki kriteria sehat.

2. Kualitas aktiva produktif

a. Rasio RPM sebesar 6.6583. sehingga rasio RPM memiliki kriteria cukup lancar.

b. Hasil penilaian rasio portofolio pembiayaan beresiko sebesar 12.8597 \% sehingga termasuk kriteria tidak beresiko.

3. Manajemen

a. Manajemen umum

Total skor untuk manajemen umum 2.4, sehingga manajemen umum berada di kriteria baik.

b. Manajemen kelembagaan

Total skor untuk manajemen kelembagaan 3, sehingga manajemen kelembagaan berada di kriteria baik.

c. Manajemen permodalan

Total skor untuk manajemen permodalan 2.4, sehingga manajemen permodalan berada di kriteria baik.

d. Manajemen aktiva

Total skor untuk manajemen aktiva 3.0, sehingga manajemen aktiva berada di kriteria baik. 
e. Manajemen likuiditas

Total skor untuk manajemen likuiditas 2.4, sehingga manajemen umum berada di kriteria baik.

4. Efisiensi

a. Hasil pengukuran rasio operasi pelayanan terhadap partisipasi bruto sebesar $95.2437 \%$, sehingga termasuk dalam kriteria kurang efisien.

b. Hasil pengukuran rasio aktiva tetap terhadap total assset adalah $25.5904 \%$ sehingga termasuk dalam kriteria baik.

5. Likuiditas

a. Hasil penghitungan. rasio kas sebesar $27.455 \%$ sehingga termasuk dalam kriteria likuid.

b. Hasil pengukuran rasio volume pembiayaan terhadap dana yang di-

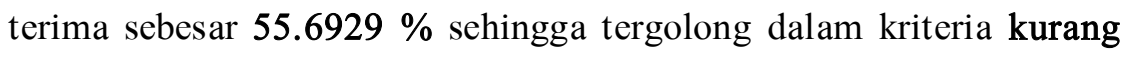
likuid.

6. Kemandirian dan pertumbuhan

Hasil penghitungan rasio ROA adalah $1.04724 \%$, sehingga termasuk dalam kriteria rendah.

7. Jati diri koperasi

Hasil penghitungan rasio partisipasi bruto sebesar $100 \%$ sehingga termasuk dalam kriteria tinggi.

Adapun saran yang mungkin bermanfaat bagi KSPS BMT RAMA Salatiga antara lain:

1. Mengintensifkan marketing untuk meningkatkan pembiayaan.

2. Meningkatkan upaya untuk menyerap dana masyarakat melalui berbagai produk funding yang ada.

3. Untuk efisiensi diharapkan ada upaya meningkatkan partisipasi bruto melalui optimalisasi kinerja karyawan. 


\section{Daftar pustaka}

Aslichan. penilaian kesehatan dalam rangka kinerja lembaga keuangan mikro syaria'ah Baitul maal wat tamwil (studi kasus BMT Bina Ummat Sejahtera Lasem Rembang Jawa Tengah).

BUKU REGISTER PEMBIAYAAN KSPS BMT RAMA SALATIGA

Hidayat, Taufiq. Analisis Tingkat Kesehatan Koperasi Jasa Keuangan.

Handayani, Ismi. 2009. Analisis Tingkat Kesehatan KSPS BMT Akbar Tahun Buku 2006-2007.

Khafid, Abdul. Tingkat Kesehataan PD BPR Kota Salatiga.

PINBUK.

RAT KSPS BMT RAMA Salatiga Tahun buku 2010.

Sudarsono, Heri. Bank dan Lembaga Keuangan Syari'ah.

Sumiyanto, Ahmad. BMT Menuju koperasi modern. ISES Pulishing: Yogyakarta.

UU Koperasi No 25 Tahun 1992. 